\title{
Summer Camps for Children with Sickle Cell Disease
}

\author{
Lauren Narcisse, BS, ${ }^{1}$ Edward A. Walton, MD, ${ }^{2}$ Lewis L. Hsu, MD, PhD ${ }^{3}$ \\ ${ }^{1}$ College of Medicine, University of Illinois at Chicago, Chicago, IL ${ }^{2}$ Medical Director, North Star Reach, Ann Arbor, MI \\ ${ }^{3}$ Department of Pediatrics, College of Medicine, University of Illinois at Chicago, Chicago, IL
}

Background: Children with sickle cell disease (SCD) face unique problems that attendance at a camp with their peers is well suited to address. However, because the staff members at ordinary summer camps are not accustomed to accommodating children with chronic diseases, the potential for significant health consequences exists.

Methods: We searched the literature in PubMed and CINAHL using the keywords summer camp, camp, sickle, and anemia to identify the unique characteristics of camps for children with SCD and the recommendations for care and/or lessons learned. Results: Published data are limited. Accommodations to avoid triggering sickle vaso-occlusive pain have been developed empirically and extrapolated from other settings. Camp experiences provide peer learning opportunities, positive role models, and a safe area to explore personal growth. The supportive atmosphere of the camp and escape from social stigma are welcome changes from the daily routine. Camp experiences can help with education on self-care and the transition from adolescent to adult healthcare.

Conclusion: Camp offers unique opportunities for care coordination. Camps for children with SCD provide a setting for dissemination of best practices for the disease. Community-based organizations should partner in recruiting young adults with SCD as counselors. Educational material now available could be modified for use in the camp setting. All stakeholders in the care of children with SCD should work in unison to ensure these children enjoy the benefits of summer camp.

Keywords: Anemia-sickle cell, camping, disabled children, minority health, patient-centered care, recreation therapy

Address correspondence to Lewis L. Hsu, MD, PhD, Professor of Pediatric Hematology-Oncology, Department of Pediatrics, College of Medicine, University of Illinois at Chicago, 840 S. Wood St., MC 856 Pediatrics, Chicago, IL 60612. Tel: (312) 996-6102.

Email: lewhsu@uic.edu

\section{INTRODUCTION}

Sickle cell disease (SCD) affects approximately 100,000 Americans, with an estimated 1,000 children born with this chronic illness every year. ${ }^{1}$ Unlike most diseases that target a specific area in the body, SCD affects the red blood cells and their response to stress. With deoxygenation, the shape of these cells changes from round to sickle-shaped. SCD can cause impaired red blood cell flow, red blood cell hemolysis, and chronic anemia and leads to multisystem complications. Acute problems may include vaso-occlusive crisis, acute chest syndrome, aplastic crisis, stroke, and hemolytic crisis. Chronic complications include renal insufficiency, pulmonary hypertension, and acute papillary necrosis. Children with SCD can miss a significant number of school days because of acute illnesses and frequent appointments, and these absences can negatively affect friendships and social life. ${ }^{2}$ Children with SCD are at high risk for depression and low self-esteem. ${ }^{2}$ They often do not have a connection with peers who share their condition, causing more difficulty in coping with the disease. Supporting psychosocial adjustment is particularly important for children with a chronic illness. ${ }^{3}$

The camping movement in America began in the late 1870s. ${ }^{4,5}$ Proponents promoted open air exposure as a way to contribute to the overall health of urban youth and to provide opportunities for exploration and personal growth. ${ }^{4}$ The movement extended to fresh air treatment for children with chronic respiratory illnesses such as tuberculosis and asthma. Wealthy families had the means to send their children to rustic summer camps. For underprivileged urban children, organizations such as the Salvation Army established camps to provide opportunities for these children to experience rural or wilderness living. Organized camping became an American tradition. ${ }^{4}$

\section{SUMMER CAMPS FOR CHRONICALLY ILL PEDIATRIC PATIENTS}

The American tradition of organized camping can be of great importance to the mental and physical health of children with chronic disease. For children with chronic disease, the summer camp experience can provide support, education, and quality of life benefits. ${ }^{6,7}$ Summer camps unite children dealing with similar medical issues so that they feel less isolated. Peer education and role modeling occur as children with the same chronic disease share the challenges of camp. Summer camp provides an intensity and density of experience and support that may be lacking during the school year. 


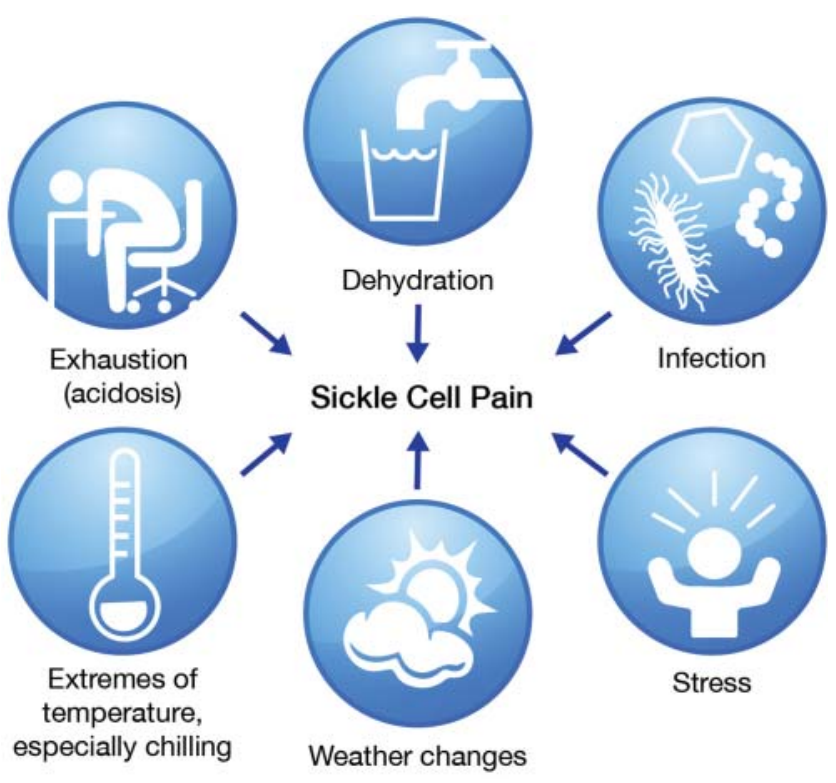

Figure. Conditions that can cause severe health consequences in children with sickle cell disease.

Children with chronic disease who attend camp report multiple benefits, including the freedom from the social stigma of their chronic disease, "opportunity to be themselves," "escape," "personal growth," "sense of belonging," and an atmosphere of "positive effect." 8 Laing and Moules argue that camp should be considered a necessary therapy for children with cancer. ${ }^{9}$

At summer camps that do not routinely care for children with serious health challenges, accommodating a child with chronic disease can be difficult. ${ }^{10}$ Fatigue, dehydration, and extremes of temperature are common occurrences for any child in summer camp. These same conditions can profoundly affect children with SCD and trigger sickle cell vaso-occlusion. The risk of vaso-occlusive crisis can inhibit participation in organized sports or informal play with healthy children. For example, vaso-constriction caused by swimming in cold water or staying in wet clothes at a water park can trigger severe sickle vaso-occlusive pain and an emergency visit to the hospital. Prolonged exertion can lead to anaerobic metabolism in a child with SCD and result in lactic acidosis, sickling, and vaso-occlusive pain. The Figure lists common conditions that can have severe health consequences for children with SCD.

\section{SUMMER CAMPS FOR CHILDREN WITH SICKLE CELL DISEASE}

Specialty summer camps for children with chronic diseases can be effective because medical support services can help the campers enjoy camp. ${ }^{11}$ However, the literature about medical issues for SCD camps is limited. A search in PubMed and CINAHL (June 13, 2018) on the keywords summer camp, camp, sickle, and anemia identified no clinical trials and only 3 descriptive papers. ${ }^{12-14}$

St Clair et al discussed a 1-week summer camp held in summer 1978 by the Sickle Cell Program of the Queen's Hospital Affiliation of the Long Island Jewish-Hillside Medical Center. ${ }^{12}$ Camp participants included children with SCD and healthy children. The primary purpose for creating the camp was to allow the children with SCD to realize that they could live a relatively normal life and to encourage them to see that they could do many of the things that healthy children could do. For example, the counselors allowed the children to go to the beach and the swimming pool once per day. The accommodations for SCD were to ensure that the children swam in the warm pool rather than the cool ocean and that the campers dried themselves immediately after leaving the water. This experience taught the children they could participate in activities such as swimming and take precautions to avoid vaso-occlusive pain. The authors noted that the camp experience created a greater sense of independence in the children with SCD and fostered new friendships, and the children wanted to know if they could return to camp the following summer. No outbreaks of disease occurred among the campers.

Powars and Brown reviewed the experience of a summer camp in California that had been active in SCD care since the late 1960s. ${ }^{13}$ The camp was for children with different types of hemoglobinopathies. In 21 of 22 years, $10 \%$ of the children had acute complications of SCD. The number of episodes was higher when the camp was held at a high-altitude mountainous site, reflecting that hypoxia and cool temperatures trigger sickling. Medical accommodations made for children with SCD were to eliminate swimming in cold mountain pools and to move the campsite to a lower altitude. The California program also adopted a paradigm that spread to most other sickle cell camps: "Success requires an experienced and prepared medical staff who leave the management of camp activities to expert recreational professionals." 13

Morrison et al described a 2009 outbreak of pandemic influenza $\mathrm{A}(\mathrm{H} 1 \mathrm{~N} 1)$ that occurred in Louisiana at a summer camp attended by children with hematologic and oncologic conditions and their nonaffected siblings. ${ }^{14}$ On the second day of camp, a healthy camper was discovered to have a fever, and the illness subsequently spread to the other campers. Overall, $36 \%$ of campers and staff were affected, with the rate highest among children and adolescents (43\%), persons with cancer (48\%), and persons with SCD (82\%). The hospitalization rate was 56 times higher for children with SCD who had the pandemic H1N1 2009 infection compared to those who were not affected.

\section{Who Organizes Sickle Cell Disease Summer Camps?}

The American Camp Association and the American Academy of Pediatrics provide general guidelines and best practices for healthcare at summer camp. ${ }^{15}$ Sickle cell community-based organizations, especially the member organizations of the Sickle Cell Disease Association of America, established many of the summer camps for children with SCD. These camps are usually medical specialty camps that are oriented toward SCD-specific education and promote specific health outcomes. ${ }^{6}$ In contrast, The Hole in the Wall Gang Camp established by actor Paul Newman is focused on children with cancer, SCD, and other blood disorders and has an adventure-based programming approach to personal growth that is rooted in experiential 
Table 1. Coping Skills and Camp Accommodations for Children With Sickle Cell Disease

\begin{tabular}{|c|c|}
\hline Coping Skill & Camp Accommodations \\
\hline Be flexible with your activity schedule. & $\begin{array}{l}\text { - Allow children to take rest breaks and drink often. } \\
\text { - Prepare accommodations for children with impaired mobility because of } \\
\text { avascular necrosis or stroke. }\end{array}$ \\
\hline Carry fluids and drink often. & $\begin{array}{l}\text { - Provide access to drinking water at all times with water bottles, water stations, } \\
\text { and water breaks. } \\
\text { - Encourage campers to drink even when they are not thirsty. } \\
\text { - Recognize that sickle cell disease is associated with a high susceptibility to } \\
\text { dehydration. }\end{array}$ \\
\hline Control your temperature. & $\begin{array}{l}\text { - Encourage campers to seek shade. } \\
\text { - Require campers to wear hats. } \\
\text { - Guard against children becoming chilled during swimming; swimming in an } \\
\text { unheated pool may trigger sickle cell pain. } \\
\text { - Require campers to take breaks from swimming every } 20-30 \text { minutes to dry off } \\
\text { and warm up, even when they are swimming in a heated pool. } \\
\text { - Adjust temperatures and/or allow campers to add layers of clothing so that they } \\
\text { do not become chilled from air conditioning. }\end{array}$ \\
\hline Cope with extreme summer heat. & $\begin{array}{l}\text { - Do not schedule heavy exertion at midday; provide quiet time. } \\
\text { - Remind campers and counselors to drink water every 30-45 minutes; have water } \\
\text { jugs and cups at every activity station. } \\
\text { - Distribute sunblock SPF } 30 \text { and above. }\end{array}$ \\
\hline $\begin{array}{l}\text { Understand that the consequences of } \\
\text { overexertion/exhaustion may be } \\
\text { days of severe pain. }\end{array}$ & $\begin{array}{l}\text { - Enforce rest breaks and reasonable bedtimes. } \\
\text { - Discourage staying up late and playing too hard because these activities may } \\
\text { lead to days of pain. } \\
\text { - Encourage counselors with sickle cell disease to be role models for prudent } \\
\text { behavior and not to be afraid to ask for help or breaks. } \\
\text { - Plan staffing flexibility so that counselors with sickle cell disease can call in } \\
\text { backups or substitutes, rather than suffering and soldiering on for the kids to the } \\
\text { detriment of their own health. }\end{array}$ \\
\hline Sense your body's warning signs. & $\begin{array}{l}\text { - Help campers learn and understand how to try to head off pain or fatigue } \\
\text { through rest, fluids, and pain medicine. } \\
\text { - Help the group be supportive of fellow campers. }\end{array}$ \\
\hline $\begin{array}{l}\text { Remember to take your daily } \\
\text { medications. }\end{array}$ & $\begin{array}{l}\text { - Help campers understand the purpose of their medications, dosages, and } \\
\text { frequency to encourage self-management. } \\
\text { - Prepare to store and administer chronic medications such as hydroxyurea, folic } \\
\text { acid, glutamine, penicillin, amoxicillin, or other antibiotics. } \\
\text { - Prepare procedures for narcotic storage and administration for pain. } \\
\text { - Prepare for storage and administration of asthma medicines that may be taken } \\
\text { on a schedule and as needed for vigorous activities. } \\
\text { - Encourage campers to adhere to medications that might be unpalatable. }\end{array}$ \\
\hline Manage bedwetting. & $\begin{array}{l}\text { - Provide absorbent disposable pads (chucks) for beds to prevent wet sheets. } \\
\text { - Change all the sheets on all the beds according to a routine to eliminate stigma. } \\
\text { - Allow campers or counselors to do their own laundry inconspicuously in the } \\
\text { morning. }\end{array}$ \\
\hline
\end{tabular}

SPF, sun protection factor.

learning theory. ${ }^{6}$ The SeriousFun Children's Network grew from the original Hole in the Wall Gang Camp and now has several camps in the United States and in other countries. ${ }^{16}$

\section{Accommodations for Sickle Cell Disease}

As previously mentioned, conditions that can cause acute problems for campers with SCD include dehydration, fatigue, and cold exposure. Accommodations for children with SCD during summer camp have been developed to prevent acute pain (Table 1). A heated pool is necessary to avoid vaso-constriction. Lakes and rivers are often too cold for children with SCD; camp directors recount children with SCD swimming in a picturesque mountain pool and then suffering the onset of severe sickle vaso-occlusive pain minutes later. Dr Howard Pearson, Yale University pediatric hematologist-oncologist, served as medical advisor for The Hole in The Wall Gang Camp and introduced innovations such as heated swimming pools and drying huts to 
Table 2. Recommended Medications, Supplies, and Equipment for Summer Camps

\begin{tabular}{|c|c|c|c|}
\hline & Medications & Supplies and Equipment & Nonmedical Equipment \\
\hline \multirow[t]{4}{*}{$\begin{array}{l}\text { Relatively unique } \\
\text { to sickle cell } \\
\text { camp }\end{array}$} & $\begin{array}{l}\text { Oral acetaminophen/ } \\
\text { hydrocodone or } \\
\text { acetaminophen/codeine }\end{array}$ & Narcotic lockbox and log sheets & $\begin{array}{l}\text { Absorbent pads for beds in case of } \\
\text { enuresis }\end{array}$ \\
\hline & IV opioids & Hot packs for analgesia & $\begin{array}{l}\text { Laundry for bed linens in case of } \\
\text { enuresis }\end{array}$ \\
\hline & IV ketorolac & & Heated swimming pool \\
\hline & IV naloxone & & $\begin{array}{l}\text { Temperature regulation in activity } \\
\text { areas }\end{array}$ \\
\hline \multirow{6}{*}{$\begin{array}{l}\text { Common to most } \\
\text { camps but } \\
\text { particularly } \\
\text { important for } \\
\text { sickle cell camps }\end{array}$} & Oral NSAIDs & Oxygen & $\begin{array}{l}\text { Ready access to water and } \\
\text { bathrooms }\end{array}$ \\
\hline & $\begin{array}{l}\text { IV ceftriaxone or other broad- } \\
\text { spectrum antibiotic }\end{array}$ & Pulse oximeter & Water bottles \\
\hline & IV normal saline & IV catheters and tubing & $\begin{array}{l}\text { Electric cart for transport of } \\
\text { campers in pain or exhaustion }\end{array}$ \\
\hline & IV hypotonic fluid & $\begin{array}{l}\text { Refrigerator for oral antibiotics and } \\
\text { other medications }\end{array}$ & Shade in activity areas \\
\hline & IV diphenhydramine & Nebulizer, tubing, aerosol mask & $\begin{array}{l}\text { Extra clothing so that campers can } \\
\text { change from wet clothes }\end{array}$ \\
\hline & Albuterol nebulizer & $\begin{array}{c}\text { Crutches/canes for assistance } \\
\text { when campers are in pain }\end{array}$ & $\begin{array}{l}\text { Bed/recliner for rest when campers } \\
\text { are in pain }\end{array}$ \\
\hline
\end{tabular}

IV, intravenous; NSAIDs, nonsteroidal antiinflammatory drugs.

avoid triggering sickle vaso-occlusive pain. Campers who transition from sweating in hot summer weather to a building with air conditioning need to have cover-ups available, and the room temperature needs to be closely monitored. One of the authors (L.L.H.) is aware of a teenager who, dressed in shorts for a hot summer day, chose to stay outdoors for conversation under the stars as the temperature dropped. She fell asleep and became so chilled that she developed sickle vaso-occlusive pain and had to leave camp for what became a 10-day hospitalization for pain management. Counselors and activity staff should be oriented to these temperature accommodations and their rationale.

A common problem with SCD is nocturnal enuresis, attributed to renal tubular dysfunction. ${ }^{17}$ Many children with SCD are reluctant to sleep away from home because of their embarrassment about enuresis. Camps should accommodate enuresis by providing disposable absorbent pads for the beds and frequent laundry service.

Three common SCD complications can lead to mobility problems for campers: acute vaso-occlusive pain in the back or legs, chronic pain from avascular necrosis (AVN) of the femoral head, and stroke. Climbing and running can be difficult and painful for campers with any of these complications, so mobility assistance may be needed. Although the incidence of stroke in SCD has decreased since the implementation of transcranial Doppler screening, some children still have stroke and sequelae of hemiparesis and/or cognitive deficits that require special disability accommodations. ${ }^{18}$

The medical team for summer campers with SCD should be prepared to manage unpredictable acute sickle vasoocclusive pain, acute infection, and acute chest syndrome. The medical team must also be ready for emergency trans- port of a camper to a facility familiar with the care of SCD. Because children with SCD have an increased risk of sepsis and sickle acute chest syndrome, every fever must be evaluated promptly and contingency plans made for empiric broad-spectrum parenteral antibiotics, intravenous fluid resuscitation, and evacuation to a hospital. The camp medical staff must organize the daily administration of medications, including the special logistics of chronic opioids and acute opioids (Table 2). The incidence of asthma is high in children with SCD, and accommodations for this comorbidity should be incorporated in the planning. ${ }^{19,20}$

Hydroxyurea for SCD, although not a cure, can reduce the susceptibility to vaso-occlusive pain and has the potential to improve exercise tolerance. ${ }^{21}$ Although no data were formally collected, one of the authors (L.L.H.) has the impression from 25 years as an SCD camp physician that hydroxyurea has reduced the incidence of vaso-occlusive pain at camp.

\section{Education in Self-Care}

Self-care is important for SCD, and summer camp can be an opportunity to learn or reinforce self-care. Children who have wondered if their parents and healthcare professionals have exaggerated the imperative for self-care can hear the same messages reinforced at camp by peers and adult role models. Studies indicate that people with SCD learn self-care best from peers with SCD. ${ }^{22,23}$ Campers can also see the practical benefits of self-care as it allows them to participate fully in camp.

Camp can be excellent preparation for the transition to the adult medical care system, widely recognized as an important goal for SCD education. ${ }^{22-24}$ Informal teaching methods such as role-playing skits, games, ${ }^{25,26}$ music, ${ }^{27,28}$ or movies (eg, The Family Legacy produced by UK Sickle Cell 
Society ${ }^{29}$ and Spilled Milk - A Documentary by Jaqai Mickelsen and Omar Beach ${ }^{30}$ ) fit well into the spirit of summer camp.

Children with SCD seldom encounter positive adult role models living with SCD in the community. In contrast, SCD camps often enlist young adults with SCD as counselors, and these individuals are critical role models for the campers. However, camp leadership can be extremely tiring, and counselors with SCD should be in tune with their health. At camp, adults with SCD should demonstrate prudent selfcare and not be afraid to ask for help or breaks. Camp organizers should plan for flexibility in staff schedules so that counselors with SCD can call in backups or substitutes.

\section{Activity Restrictions}

SCD often limits endurance, correlated primarily with the severity of anemia. Children with SCD can participate in a variety of physical activities at moderate to vigorous intensity but have been reported to tolerate shorter durations of activity than healthy children. ${ }^{31-33}$ The implications for summer camp include scheduling rest breaks between activities and during walks between camp locations.

As mentioned earlier, some children have impaired gait because of AVN or stroke, and the duration of walking and any inclines can cause hardship. Also, mechanical stresses such as those provided by a trampoline could be difficult for children with impaired gait.

\section{DIFFERENCES BETWEEN SICKLE CELL DISEASE CAMPS AND OTHER CHILDREN'S CAMPS}

Staff orientation prior to the start of camp for children with SCD should acknowledge some unique characteristics of the disease. SCD is a mystery to most Americans, unlike common diseases such as asthma and diabetes. The inherited nature of SCD makes it unlike cancer, so children with SCD cannot segment their lives the way children with cancer can divide their lives into before cancer, on treatment, and survivor. Finally, SCD disproportionately affects minority ethnic groups; at some camps, the week of summer devoted to SCD camp is the only time that significant numbers of African Americans are in attendance, and the staff needs to exercise cultural sensitivity.

\section{FUTURE PROGRESS}

Camps for children with SCD can build upon current success in many ways. Manuals should be developed and disseminated with documentation of standards that prepare and engage the recreational staff and the medical team to make the preparations and accommodations required for the disease. Community-based organizations should partner with the stakeholders that host summer camps for children with SCD and recruit young adults with SCD as counselors. Research on the impact of SCD camps (care, adolescent transition, self-management, quality of life, and adult coping) should be conducted. Engaging educational material suitable for the camp setting could be developed and disseminated widely for evaluation. Finally, established subject matter experts such as the SeriousFun Children's Network, the American Academy of Pediatrics, the American Camp Association, and the Sickle Cell Disease Association of America should collaborate on and disseminate best practices so that children with SCD across the country can enjoy the myriad benefits of summer camp.

\section{CONCLUSION}

Camps for children with SCD offer unique opportunities for care coordination and provide a setting for dissemination of best practices for the disease. For campers, benefits include peer learning opportunities, positive role models, a safe area to explore personal growth, and a supportive atmosphere. Camp experiences can also educate children on self-care and the transition from adolescent to adult care. All stakeholders in the care of children with SCD should work in unison to ensure these children enjoy the benefits of summer camp.

\section{ACKNOWLEDGMENTS}

Dr Edward Walton is the Medical Director of Camp North Star Reach, a member camp of the SeriousFun Children's Network of camps. He and the other authors have no financial or proprietary interest in the subject matter of this article.

TaLana Hughes, MPH, and Linda Drawhorne, RN, of the Sickle Cell Disease Association of Illinois provided valuable input.

\section{REFERENCES}

1. Data and statistics on sickle cell disease. Centers for Disease Control and Prevention. www.cdc.gov/ncbddd/sicklecell/data .html. Reviewed August 9, 2017. Accessed June 18, 2018.

2. Daniel LC, Li Y, Smith K, et al. Lessons learned from a randomized controlled trial of a family-based intervention to promote school functioning for school-age children with sickle cell disease. J Pediatr Psychol. 2015 Nov-Dec;40(10):1085-1094. doi: 10.1093/jpepsy/jsv063.

3. Gilmore V. How special needs camping has impacted the camp experience. Camping Magazine. American Camp Association. https://www.acacamps.org/resource-library/camping-magazine /how-special-needs-camping-has-impacted-camp-experience. Published January 2016. Accessed October 3, 2018.

4. Ramsing R. Organized camping: a historical perspective. Child Adolesc Psychiatr Clin N Am. 2007 Oct;16(4):751-754, v.

5. Garst BA, Browne LP, Bialeschki MD. Youth development and the camp experience. New Dir Youth Dev. 2011 Summer;2011 (130):73-87. doi: 10.1002/yd.398.

6. Carlson KP, Cook M. Challenge by choice: adventure-based counseling for seriously ill adolescents. Child Adolesc Psychiatr Clin N Am. 2007 Oct;16(4):909-919, viii.

7. Cushner-Weinstein S, Berl M, Salpekar JA, et al. The benefits of a camp designed for children with epilepsy: evaluating adaptive behaviors over 3 years. Epilepsy Behav. 2007 Feb;10(1):170-178.

8. Gillard A, Allsop J. Camp experiences in the lives of adolescents with serious illnesses. Child Youth Serv Rev. 2016 Jun;65:112119. doi: 10.1016/j.childyouth.2016.04.001.

9. Laing CM, Moules NJ. "It's not just camp!": understanding the meaning of children's cancer camps for children and families. J Pediatr Oncol Nurs. 2016 Jan-Feb;33(1):33-44. doi: 10.1177/ 1043454214563934.

10. Page CJ, Pearson J. Creating therapeutic camp and recreation programs for children with chronic illness and disabilities. Pediatrician. 1990;17(4):297-307.

11. Moola FJ, Faulkner GE, White L, Kirsh JA. The psychological and social impact of camp for children with chronic illnesses: a systematic review update. Child Care Health Dev. 2014 Sep;40 (5):615-631. 
12. St Clair L, Rosner F, Karayalcin G. Experience of children with sickle cell anemia in a regular summer camp. J Natl Med Assoc. 1979 Nov;71(11):1144-1146.

13. Powars DR, Brown M. Sickle cell disease. Summer camp. Experience of a 22-year community-supported program. Clin Pediatr (Phila). 1990 Feb;29(2):81-85.

14. Morrison C, Maurtua-Neumann P, Myint MT, Drury SS, Bégué RE. Pandemic (H1N1) 2009 outbreak at camp for children with hematologic and oncologic conditions. Emerg Infect Dis. 2011 Jan;17(1):87-89. doi: 10.3201/eid1701.091499.

15. Council on School Health, Walton EA, Tothy AS. Creating healthy camp experiences. Pediatrics. 2011 Apr;127(4):794-799. doi: 10.1542/peds.2011-0267.

16. SeriousFun Children's Network. www.seriousfunnetwork.org. Accessed October 3, 2018.

17. Wolf RB, Kassim AA, Goodpaster RL, DeBaun MR. Nocturnal enuresis in sickle cell disease. Expert Rev Hematol. 2014 Apr;7 (2):245-254. doi: 10.1586/17474086.2014.892412.

18. Estcourt LJ, Fortin PM, Hopewell S, Trivella M, Wang WC. Blood transfusion for preventing primary and secondary stroke in people with sickle cell disease. Cochrane Database Syst Rev. 2017 Jan 17;1:CD003146. doi: 10.1002/14651858.CD003146.pub3.

19. Gomez E, Morris CR. Asthma management in sickle cell disease. Biomed Res Int. 2013;2013:604140. doi: 10.1155/2013/604140.

20. Cohen RT, Klings ES, Strunk RC. Sickle cell disease: wheeze or asthma? Asthma Res Pract. 2015 Dec 8;1:14. doi: 10.1186/ s40733-015-0014-2.

21. Wali YA, Moheeb $\mathrm{H}$. Effect of hydroxyurea on physical fitness indices in children with sickle cell anemia. Pediatr Hematol Oncol. 2011 Feb;28(1):43-50. doi: 10.3109/ 08880018.2010 .524278 .

22. Jordan L, Swerdlow P, Coates TD. Systematic review of transition from adolescent to adult care in patients with sickle cell disease. J Pediatr Hematol Oncol. 2013 Apr;35(3):165-169. doi: 10.1097/MPH.0b013e3182847483.

23. de Montalembert M, Guitton C; French Reference Centre for Sickle Cell Disease. Transition from paediatric to adult care for patients with sickle cell disease. Br J Haematol. 2014 Mar;164 (5):630-635. doi: 10.1111/bjh.12700.
24. Treadwell M, Johnson S, Sisler I, et al. Development of a sickle cell disease readiness for transition assessment. Int J Adolesc Med Health. 2016 May 1;28(2):193-201. doi: 10.1515/ijamh2015-0010.

25. Yoon SL, Godwin A. Enhancing self-management in children with sickle cell disease through playing a CD-ROM educational game: a pilot study. Pediatr Nurs. 2007 Jan-Feb;33 (1):60-63, 72.

26. Jeopardy Labs. 2017. jeopardylabs.com. Accessed June 20, 2018.

27. Rodgers-Melnick SN, Pell TJG, Lane D, et al. The effects of music therapy on transition outcomes in adolescents and young adults with sickle cell disease. Int J Adolesc Med Health. 2017 Aug 5. doi: 10.1515/ijamh-2017-0004.

28. Rodgers-Melnick SN, Matthie N, Jenerette C, et al. The effects of a single electronic music improvisation session on the pain of adults with sickle cell disease: a mixed methods pilot study. $J$ Music Ther. 2018 Jun 7;55(2):156-185. doi: 10.1093/jmt/thy004.

29. Thoburn J, Solanke A. The Family Legacy - A drama about sickle cell disease [video]. London: UK Sickle Cell Society; 2009. www.sicklecellsociety.org/resource/the-family-legacy/. Accessed October 3, 2018.

30. Mickelsen J, Beach O. Spilled Milk - A Documentary [video]. Atlanta 2018. www.spilledmilkmovie.com. Accessed October 3 , 2018.

31. Hostyn SV, Carvalho WB, Johnston C, Braga JA. Evaluation of functional capacity for exercise in children and adolescents with sickle-cell disease through the six-minute walk test. $J$ Pediatr (Rio J). 2013 Nov-Dec;89(6):588-594. doi: 10.1016/j. jped.2013.04.005.

32. Omwanghe OA, Kwon S, Muntz DS, et al. Habitual physical activity and exercise patterns in children and adolescents with sickle cell disease. Blood. 2014;124:4099.

33. Omwanghe OA, Muntz DS, Kwon S, et al. Self-reported physical activity and exercise patterns in children with sickle cell disease. Pediatr Exerc Sci. 2017 Aug;29(3):388-395. doi: 10.1123/ pes.2016-0276.

This article meets the Accreditation Council for Graduate Medical Education and the American Board of Medical Specialties Maintenance of Certification competencies for Patient Care and Medical Knowledge. 